Al Qalam: Jurnal Ilmiah Keagamaan dan Kemasyarakatan

https://jurnal.stiq-amuntai.ac.id/index.php/al-qalam

P-ISSN: 1907-4174; E-ISSN: 2621-0681

DOI : 10.35931/aq.v16i1. 854

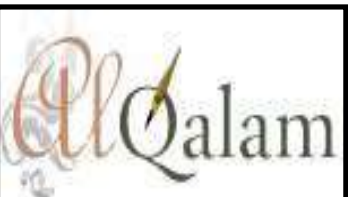

\title{
RISK AND RETURN MODEL OF DIGITAL CRYPTOCURRENCY ASSET INVESTMENT IN INDONESIA
}

\author{
Rico Nur Ilham, Isfenti Sadalia*2, Nisrul Irawati ${ }^{3,}$ Irada Sinta $^{4}$ \\ ${ }^{1}$ Faculty of Economic and Business, Universitas Malikussaleh \\ ${ }^{2,3}$ Postgraduate School Department of Management, Universitas Sumatera Utaral \\ ${ }^{4}$ Faculty of Agriculture, Universitas Malikussaleh
}

Coresponding Author: Isfenti@usu.ac.id

\begin{abstract}
Cryptocurrency is an investment commodity that can generate returns and already has a license to be traded in exchange trading through the Indonesian Commodity Futures Trading Regulatory Agency (BAPEPTI). There are quite a lot of crypto digital assets traded in Indonesia through the trading company Indodax. The purpose of this research is focused on formulating a risk management process in cryptocurrency digital asset investment. In addition, from the results of this study, a policy recommendation known as LCTR or "Legal Cryptocurrency and Tax Revenue" is expected to be considered by the government in formulating policies on crypto digital assets so that the interests of all parties can be accommodated for the realization of maximum state revenue from commodity trading. crypto digital assets. This type of research is quantitative descriptive with the research population, namely 5 cryptocurrency coins with the largest market caps in Indonesia, namely Bitcoin, Ethereum, Ripple, Bitcoin Cash, Litecoin in Indonesia. The type of data in this study is time series data taken from March 2021 to December 2021 by conducting a documentation study conducted on the publication of monthly cryptocurrency transaction reports, so that a target population of 240 (4 years $x$ 12 months $x 5$ coins) monthly report data is obtained. for the research sample. The data analysis method in this study used multiple linear regression and data analysis used statistical software e-views version 10. The output of this study was the publication of reputable international journals,
\end{abstract}

Keywords—risk management, digital assets, cryptocurrency

\section{INTRODUCTION}

Investment is an investment directly or indirectly, as well as short and long term with the aim of obtaining the expected profit or other forms of benefits from the investment itself. From this investment there is a desired return. One of the most important parts of studying investing is how to measure risk and return. The expected profit (Expected Return) is the return that investors will get in the future. In reality, almost all investments contain uncertainty or risk. ${ }^{1}$ Market capitalization, Cryptocurrency Bitcoin is the highest among other cryptocurrencies based on May 302018 data,

${ }^{1}$ Eduardus Tandelilin, Portofolio Dan Investasi (Kanisius, 2010).

Al Qalam: Jurnal Ilmiah Keagamaan dan Kemasyarakatan Vol. 16, No. 1 Januari - Juni 2022 
Rico Nur Ilham, Isfenti Sadalia, Nisrul Irawati, Irada Sinta : Risk dan Return Model of Digital Cryptocurrency Asset Investmen in Indonesia

the market capitalization value of Bitcoin reached US\$ 128.10 billion, followed by Ethereum with a market capitalization of US $\$ 58.57$ billion. $^{2}$

This study examines the issues that are debatable in the investment world, namely the characteristics of the cryptocurrency sales market instrument in Indonesia which have similarities with the IDX sales market instrument in terms of return and risk. Return is measured by capital gains while risk is measured by capital loss or a decrease in the price of the investment instrument. ${ }^{3}$ Cryptocurrency or crypto currency is increasingly being recognized by many people in Indonesia. This can be seen from the representation of the blockchain whose impact can be enjoyed directly by the public (consumers), and there are many other potentials that can be explored, so that interest in cryptocurrencies, generally as an investment instrument, actually only increased sharply after the Bitcoin exchange rate experienced a sharp spike. high enough.

In particular, this study carried out a Focus Group Discussion by inviting financial experts and leaders of the financial services industry with the aim of gathering input and suggestions from the draft policy recommendations resulting from the research process. Because the regulation of the crypto digital asset market or better known as cryptocurrencies in Indonesia is still very minimal, however, cryptocurrency investment continues to increase. This is marked by the emergence of various exchanges or companies that act as intermediaries in buying and selling crypto assets. In early August 2021, Tokocrypto will come, where Tokocrypto, a local exchange based in Jakarta, will be officially launched.

The entire process carried out in this study resulted in several instruments in the form of policy recommendations and formulation of investment strategies as well as risk control models and are later expected to assist investors in choosing investment strategies and decisions, especially digital crypto assets in Indonesia by considering risk factors. This is supported by the development of many cryptocurrency trading exchange companies that have carried out soft launches in May 2017 and sold two types of crypto, namely Bitcoin and Ethereum. Another exchange that has been operating since 2014, namely Indodax under the name Bitcoin Indonesia, has 1,337,839 users.

\section{PROBLEM REVIEW}

\subsection{Risk Management}

Risk management can be defined as a structured and systematic process of identifying, measuring, mapping, developing alternative risk management, and monitoring and controlling the

${ }^{2}$ Rico Nur Ilham et al., "Positive Effect in Efficient Application of Corporate Social Responsibility in PT.Indonesia Asahan Aluminium as an Indicator Enhancement Efforts Public Welfare North Sumatra," 2019.

${ }^{3}$ Rico Nur Ilham, "Pengaruh Manajemen Laba Terhadap Nilai Perusahaan Dengan Good Corporate Governance," 2017.

Al Qalam: Jurnal Ilmiah Keagamaan dan Kemasyarakatan Vol. 16, No. 1

Januari - Juni 2022 
Rico Nur Ilham, Isfenti Sadalia, Nisrul Irawati, Irada Sinta : Risk dan Return Model of Digital Cryptocurrency Asset Investmen in Indonesia

implementation of risk management. Ali argues that risk management is an action taken to avoid risks that may arise in the future. ${ }^{4}$ Risk consists of pure risk and speculative risk (pure risk and speculative risk), risk to objects and people, fundamental risk and special risk (fundamental risk and particular risk). ${ }^{5}$

\subsection{Signaling Theory}

Signaling theoryis an effect that arises from the announcement of financial statements that are captured by users of financial statements, especially investors. Signaling effects are generated by new information, and not by existing issues. ${ }^{6}$ Signal theory suggests the importance of information issued by companies to investment decisions. If the announcement is announced as a good signal for investors thenthere will be changes in the volume of stock trading. ${ }^{7}$ Complete, relevant, accurate and timely information is needed by capital market investors as a tool to analyze before making a decision to invest.

\subsection{Capital Asset Pricing Model}

In calculating the level of portfolio returns, investors need analytical tools. The general balance model allows investors to measure risk and return. ${ }^{8}$ One of them is the Capital Asset Pricing Model (CAPM). Asset pricing model (asset pricing model) is an important part in terms of finance that is used to predict the relationship between expected return and risk of an asset. The asset pricing model continues to develop along with the many criticisms directed at the first asset pricing model, namely the Capital Asset Pricing Model (CAPM).

\subsection{Economic Theory of Regulation}

Banking regulations in Indonesia are generally applied in Bank Indonesia regulations through circulars which are always updated or amended according to the conditions and situations of the national banking system. according to Siringoringo $0^{9}$ as a developer of the economic theory of regulation, regulation is an act of suppression of groups that produces laws and policies to support business and protect consumers, workers, and the environment.

\subsection{Research Framework}

${ }^{4}$ Mashud Ali, Risk Management (Banking and Business Strategy in Facing the Challenges of Business Globalization) (Jakarta: PT Raja Grafindo Persada, 2006).

${ }^{5}$ M. Labombang, "Risk Management in Construction Projects," SMARTek Journal, no. 9 (2011).

6 Stephen Penman and Francesco Reggiani, "Returns to Buying Earnings and Book Value: Accounting for Growth and Risk," Review of Accounting Studies 18, no. 4 (2013): 1021-49.

7 Hartono Jogiyanto, Misguided Business Research Methodology and Experiences, 5th ed. (Yogyakarta: BPFE-Yogyakarta, 2013).

${ }^{8}$ LJ Gitman and CJ Zutter, Principles of Managerial Finance (Pearson: Boston, 2012). (2012): 1-24.

${ }^{9}$ Renniwaty Siringoringo, "Perbankan Di Indonesia," Buletin Ekonomi Moneter Dan Perbankan juli

Al Qalam: Jurnal Ilmiah Keagamaan dan Kemasyarakatan Vol. 16, No. 1 Januari - Juni 2022 
Rico Nur Ilham, Isfenti Sadalia, Nisrul Irawati, Irada Sinta : Risk dan Return Model of Digital Cryptocurrency Asset Investmen in Indonesia

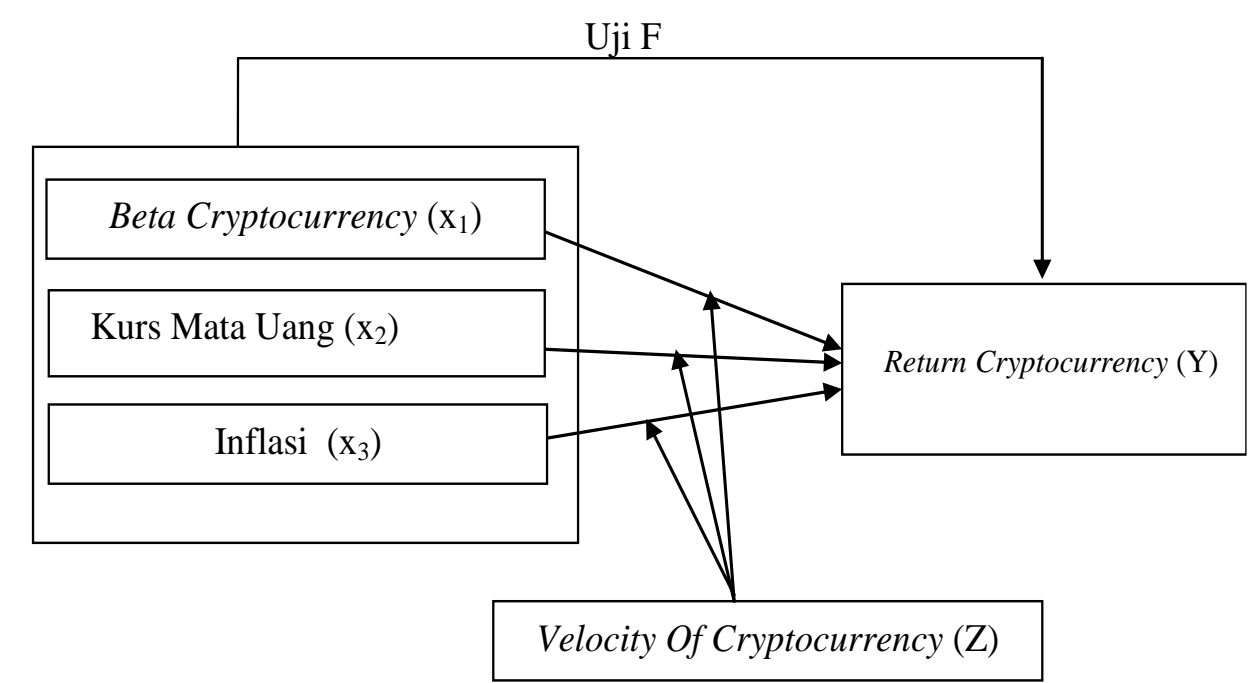

Figure 1. Research Framework

\subsection{Roadmap Study}

The following is a research roadmap risk factor-based crypto digital asset investment return assessment:

\begin{tabular}{|c|c|}
\hline Tahun Pertama & Tahun Kedua \\
\hline $\begin{array}{l}\text { 1.Perancangan Konsep } \\
\text { Penelitian } \\
\text { 2.Pengumpulan } \\
\text { Literatur review } \\
\text { 3.Pematangan Konsep } \\
\text { Penelitian Risiko } \\
\text { cryptocurrency } \\
\text { 4.Pengumpulan Data } \\
\text { Penelitian } \\
\text { 5.Output hasil } \\
\text { penelitian effect of } \\
\text { unsystematic Risk on } \\
\text { Return Cryptocurrency }\end{array}$ & $\begin{array}{l}\text { 1.Pengembangan } \\
\text { Output Penelitian } \\
\text { Unsystematic Risk } \\
\text { 2.Penambahan Konsep } \\
\text { Resiko Makroekonomi } \\
\text { dalam penelitian dan } \\
\text { komoditas logam mulia } \\
\text { 3.Pengkajian Literatur } \\
\text { Review systematic Risk } \\
\text { 4.Pengumpulan Data } \\
\text { Penelitian } \\
\text { 4.Output hasil } \\
\text { penelitian effect of } \\
\text { systematic risk and gold } \\
\text { price on return } \\
\text { cryptocurrency }\end{array}$ \\
\hline
\end{tabular}

Tahun Ketiga
1.Pengembangan
Output Penelitian
Systematic risk and gold
price
2.Justifikasi hasil
penelitian terhadap
stabilitas system
keuangan
3.Pengkajian literatur
review
4.Pengumpulan Data
Penelitian
5.Output Hasil
Penelitian Risk Factor
Model of cryptocurrency
and gold price on money
stability

Al Qalam: Jurnal Ilmiah Keagamaan dan Kemasyarakatan Vol. 16, No. 1 Januari - Juni 2022 
Rico Nur Ilham, Isfenti Sadalia, Nisrul Irawati, Irada Sinta : Risk dan Return Model of Digital Cryptocurrency Asset Investmen in Indonesia

Figure 2. Research Roadmap for assessing risk factor-based crypto digital asset investment returns

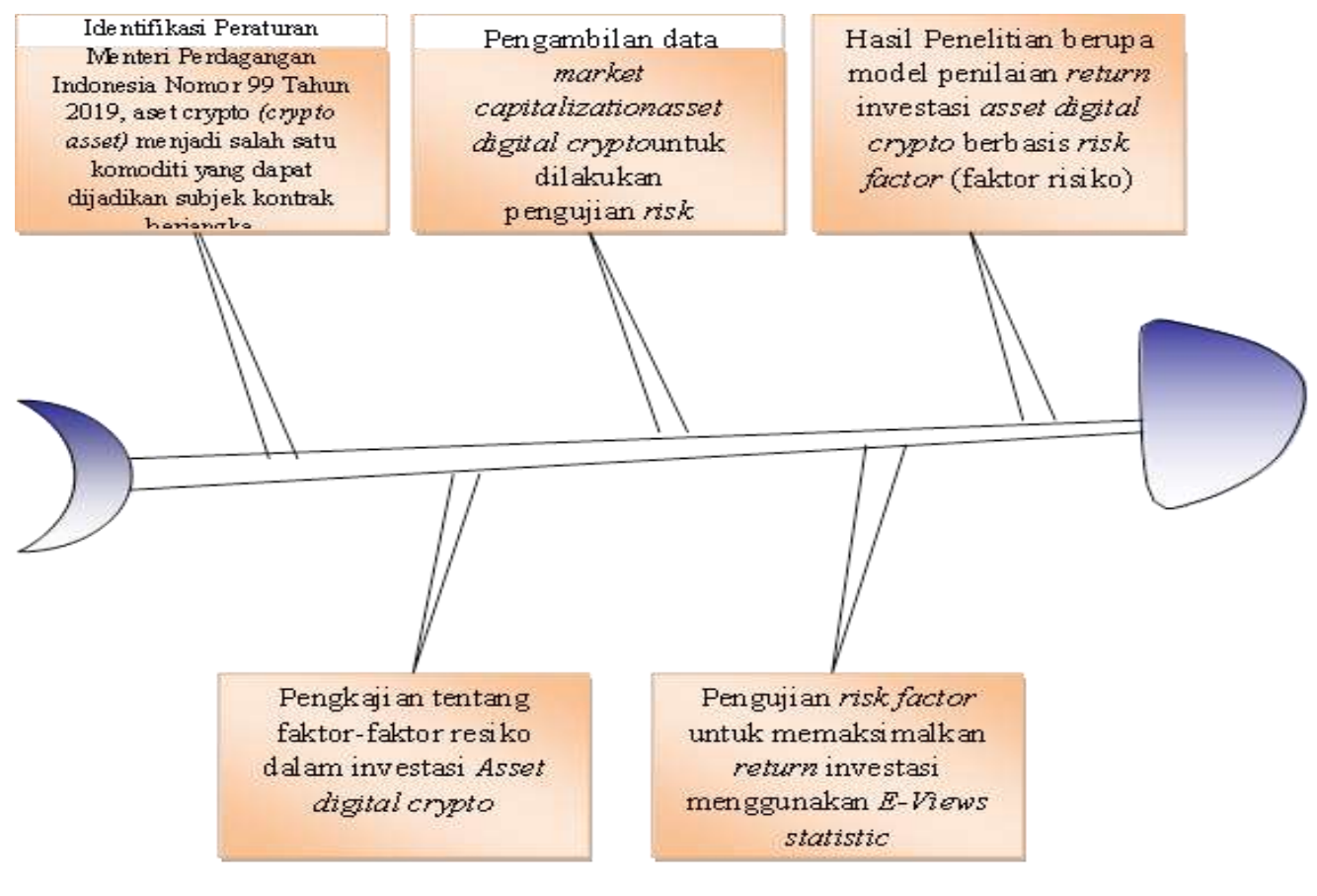

Research Flowchart

Figure 3. Flowchart of Fish Bone in the Research Stage Plan

\section{RESULTS AND DISCUSSION}

\subsection{Type Study}

This type of research is descriptive quantitative, namely critical observation to obtain accurate information on a particular problem and object in a particular community group area or location will be studied or described or described a situation as clearly as possible without any treatment of the object under study. ${ }^{10}$ The type of data used in this study is secondary data obtained from monthly transaction reports of digital cryptocurrencies in Indonesia.

\subsection{Population and Sample}

The population of this study is all Cryptocurrency digital assets traded on crypto trading exchanges in Indonesia. While the sample in this study is cryptocurrency which has the largest market capitalization value in Indonesia.

\subsection{Research methods}

This study uses the explanatory case study method to explain the influence between the 2012.

${ }^{10}$ Ruslan Ghofur, "Distribution Policy on Islamic Economics," Islamic Journal of Islamic Studies,

Al Qalam: Jurnal Ilmiah Keagamaan dan Kemasyarakatan Vol. 16, No. 1

Januari - Juni 2022 
Rico Nur Ilham, Isfenti Sadalia, Nisrul Irawati, Irada Sinta : Risk dan Return Model of Digital Cryptocurrency Asset Investmen in Indonesia

variables used in this study through testing the research hypotheses that have been determined. While the technique used is Cross Sectional This analysis is used to determine the magnitude of the influence of the independent variable on the dependent variable.

\subsection{Organizational Structure of the Proposing Team and Division of Tasks}

\begin{tabular}{|c|c|c|c|c|}
\hline No. & Name /NIDN/NIP & Faculty/Unit & $\begin{array}{l}\text { Knowledge } \\
\text { field }\end{array}$ & Job description \\
\hline 1 & $\begin{array}{l}\text { Prof. Dr. Isfenti Sadalia, } \\
\text { ME / NIDN } \\
0019106702\end{array}$ & $\begin{array}{c}\text { faculty of } \\
\text { Economics } \\
\text { and Business }\end{array}$ & $\begin{array}{c}\text { Financial } \\
\text { Management }\end{array}$ & $\begin{array}{l}\text { 1. Pre survey research } \\
\text { 2. Preparation of research } \\
\text { instruments } \\
\text { 3. Relevant data retrieval }\end{array}$ \\
\hline 2 & $\begin{array}{l}\text { Dr. Nisrul Irawati, } \\
\text { MBA/NIDN } \\
0004126207\end{array}$ & $\begin{array}{c}\text { faculty of } \\
\text { Economics } \\
\text { and Business }\end{array}$ & $\begin{array}{c}\text { Financial } \\
\text { management }\end{array}$ & $\begin{array}{l}\text { 1. Making research } \\
\text { phenomena } \\
\text { 2. Pre survey research } \\
\text { 3. Data retrieval and } \\
\text { analysis } \\
\text { 4. Research report writing }\end{array}$ \\
\hline
\end{tabular}

\section{RESULTS AND DISCUSSION}

Descriptive statistics is a part of statistical science that summarizes, presents and describes data in an easy-to-read form so as to provide more complete information. Descriptive statistics are only related to describing or providing information about a data or situation or phenomenon, in other words only seeing a general picture of the data obtained. The state of the data in this study is presented in the following descriptive statistical table:

Table 4.1

Descriptive Statistics of Research Variables

\begin{tabular}{|c|c|c|c|c|c|}
\hline Variable & $\begin{array}{c}\text { Return } \\
\text { Cryptocu } \\
\text { rrency } \\
(\mathrm{Y})\end{array}$ & $\begin{array}{c}\text { Cryptocur } \\
\text { rency Beta } \\
(\mathrm{X} 1)\end{array}$ & $\begin{array}{c}\text { Currency } \\
\text { Exchang } \\
\mathrm{e} \\
(\mathrm{X} 2)\end{array}$ & $\begin{array}{c}\text { Inflation } \\
\text { Rate (X3) }\end{array}$ & $\begin{array}{c}\text { Velocity } \\
\text { of } \\
\text { rryptocucy } \\
(\mathrm{Z})\end{array}$ \\
\hline Mean & 14.21 & -0.008 & 13613 & 0.270 & 0.575 \\
\hline Minimum & -58.41 & -4.201 & 12625 & -0.450 & 0.001 \\
\hline Maximum & 740.41 & 0.228 & 15227 & 0.970 & 2,555 \\
\hline Std. Dev. & 69.71 & 0.277 & 551.77 & 0.325 & 0.658 \\
\hline Observations & 240 & 240 & 240 & 240 & 240 \\
\hline
\end{tabular}

Source: Descriptive Statistical Data Processing Results, 2021.

Based on Table 5.1 above, the following can be explained:

a. Average Cryptocurrency Return (Y) of 14.21, minimum value of -58.41 (11 months of 2018 on Bitcoin Cash), the maximum value is 740.41 (12 months of 2017 on Ripple), and the standard deviation of 69.71 with the number of observations (n) of 240 . The average value of Return

Al Qalam: Jurnal Ilmiah Keagamaan dan Kemasyarakatan Vol. 16, No. 1 Januari - Juni 2022 
Rico Nur Ilham, Isfenti Sadalia, Nisrul Irawati, Irada Sinta : Risk dan Return Model of Digital Cryptocurrency Asset Investmen in Indonesia

Cryptocurrency (Y) is close to the standard deviation of 69.71, thus data deviation Return Cryptocurrency (Y) low. The average value of Return Cryptocurrency (Y) is 14.21 which means investment in ccryptocurrency Bitcoin Cash, Litecoin, Ripple, Ethereum, Bitcoin can provide Cryptocurrency Returns of 14.21 percent.

b.Average Cryptocurrency Beta (X1)as big as -0.008 minimum value of -4,201 (12 months of 2017), the maximum value is 0.228 (11th month of 2017), and the standard deviation of 0.277with the number of observations (n) of 240. The average value Cryptocurrency Beta (X1)close to the standard deviation value of 0.277 thus data deviation of Beta Cryptocurrency (X1) low. This means, ifCryptocurrency Beta (X1)has increased, it can decrease the Return Cryptocurrency (Y). Cryptocurrency return is the systematic risk of a cryptocurrency portfolio investment against market risk or the volatility of a cryptocurrency portfolio return on market returns.

c. Average Currency Exchange Rate (X2) of 13,613, minimum value of 12,625 (1 month of 2015), the maximum value is 15,227 (10th month of 2018), and the standard deviation of 551.77with the number of observations (n) of 240. The average value of the Currency Exchange (X2) is close to the standard deviation of 551.77, thus data deviation Currency Rate (X2) is low. This means, if the Currency Exchange (X2)has increased, it can decrease the Return Cryptocurrency (Y). Currency exchange rate is the price of a currency of a country measured or expressed in another currency.

d.Average Inflation Rate (X3) of0.270, minimum value of -0.450 (4th month of 2016), the maximum value is 0.970 ( 1 month of 2017), and the standard deviation of 0.325 with the number of observations (n) of 240. The average value of the inflation rate (X3) is close to the standard deviation of0.325 thus data deviation The Inflation Rate (X3) is low. This means, if the Inflation Rate (X3) has increased, it can decrease the Cryptocurrency Return (Y). Inflation is an event that describes the situation and conditions where the price of goods has increased and the value of the currency has weakened.

e. Average Velocity of Cryptocurrency $(Z)$ is 0.575 minimum value of 0.001 (11th month of 2016), the maximum value is 2,555 (12 months of 2017), and the standard deviation of 0.658 with the number of observations (n) of 240. The average value of Velocity of Cryptocurrency (Z) is close to the standard deviation of 0.658 , thus the data deviation Velocity of Cryptocurrency (Z) low. Cryptocurrency Circulation Speed of 0.575 which means speed of crypto changing hands determined by the price and money circulation of 0.575 times. Low velocity means that crypto assets last longer in the wallet, meaning that investors who initially tried to speculate on asset purchases quickly are now turning to holders or people who hold crypto for the long term. The

Al Qalam: Jurnal Ilmiah Keagamaan dan Kemasyarakatan Vol. 16, No. 1

Januari - Juni 2022 
Rico Nur Ilham, Isfenti Sadalia, Nisrul Irawati, Irada Sinta : Risk dan Return Model of Digital Cryptocurrency Asset Investmen in Indonesia

velocity/velocity of crypto tokens moving cannot be determined or measured in a short time and other factors in this method are also not easy to measure and estimate (other factors are assumed to be constant).

\subsubsection{Data Stationarity Test}

Stationary test is a test conducted to determine that time series data is not affected by time. Stationary is a time series data condition which if the average, variance and covariance of these variables are not entirely influenced by time. ${ }^{11}$ Stationarity and unit root testing methods that will be used here are the Augmented Dickey Fuller (ADF) and Phillips Perron (PP) methods. The following is the stationarity test of the data research variable:

Table 4.2

Test Data Stationarity Research variable

\begin{tabular}{|c|c|c|c|c|c|}
\hline Variable & $\begin{array}{l}\text { Return } \\
\text { Cryptocur } \\
\text { rency }(\mathrm{Y})\end{array}$ & $\left\{\begin{array}{c}\text { Cryptocurr } \\
\text { ency Beta } \\
\text { (X1) }\end{array}\right.$ & $\begin{array}{l}\text { Currency } \\
\text { Rate (X2) }\end{array}$ & $\begin{array}{c}\text { Inflation } \\
\text { Rate (X3) }\end{array}$ & $\begin{array}{c}\text { Velocity of } \\
\text { Cryptocur } \\
\text { rency }(\mathrm{Z})\end{array}$ \\
\hline DF Value & $-13,607$ & $-15,475$ & -3.993 & $-3,290$ & $-2,667$ \\
\hline $5 \%$ & -1.9421 & $-1,942$ & $-1,942$ & $-1,942$ & $-1,942$ \\
\hline ADF Value & $-14,083$ & $-15,532$ & -6.292 & $-8,245$ & $-3,900$ \\
\hline Probability & 0.0000 & 0.0000 & 0.0000 & 0.0000 & 0.0024 \\
\hline Description & Stationary & Stationary & Stationary & Stationary & Stationary \\
\hline
\end{tabular}

Source: Descriptive Statistical Data Processing Results, 2021.

Based on the results of data processing, the DF value (t-statistics) $>$ from DF (t-statistics) at $5 \%$ alpha and the ADF value (t-statistics) with the probability value of all variables $<0.05$, it is concluded that the Return Cryptocurrency variable (Y), Cryptocurrency Beta (X1), Currency Rate (X2), Inflation Rate (X3), and stationary Velocity of Cryptocurrency (Z). So that regression analysis can be estimated.

\subsubsection{Panel Data Regression Model}

\section{a. Common Effect Model (CEM)}

This method uses the Ordinary Least Square (OLS) approach or the least squares technique to estimate the panel data model. Based on the results of calculations using the computer statistical program Eviews, the following results were obtained:

Table 5.3

Common Effect Model (CEM) Results

\begin{tabular}{|c|r|r|r|r|}
\hline Variable & Coefficient & Std. Error & t-Statistics & Prob. \\
\hline X1 & -3.763608 & 0.728877 & -5.163568 & 0.0000 \\
\hline X2 & -0.128047 & 0.125496 & -1.020327 & 0.3087 \\
\hline X3 & -0.000306 & $8.78 \mathrm{E}-05$ & -3.483268 & 0.0006 \\
\hline
\end{tabular}

${ }^{11}$ Bambang Juanda, "Ekonometrika Deret Waktu: Teori Dan Aplikasi," 2012, 1-6.

Al Qalam: Jurnal Ilmiah Keagamaan dan Kemasyarakatan Vol. 16, No. 1 Januari - Juni 2022 
Rico Nur Ilham, Isfenti Sadalia, Nisrul Irawati, Irada Sinta : Risk dan Return Model of Digital Cryptocurrency Asset Investmen in Indonesia

\begin{tabular}{|l|r|l|r|r|}
\hline \multicolumn{1}{|c|}{ Z_X1 } & 0.841937 & 0.290437 & 2.898857 & 0.0041 \\
\hline Z_X2 & 0.169484 & 0.195497 & 0.866939 & 0.3869 \\
\hline C & 3.694364 & 1.246360 & 2.964123 & 0.0034 \\
\hline R-squared & 0.561607 & Mean dependent var & & 0.142107 \\
\hline Adjusted R-squared & 0.538432 & SD dependent var & 0.697110 \\
\hline SE of regression & 0.473608 & Akaike info criterion & 1.395772 \\
\hline Sum squared resid & 50.91720 & Schwarz criterion & & 1.584307 \\
\hline Likelihood logs & -154.4927 & Hannan-Quinn Criter. & 1.471738 \\
\hline F-statistics & 24.23335 & Durbin-Watson stat & 1.787175 \\
\hline Prob(F-statistic) & 0.000000 & & \\
\hline
\end{tabular}

Source: Appendix 5 data processed 2021

b. Fixed Effect Model (FEM)

Fixed Effect Model (FEM) assumes that differences between individuals can be accommodated from differences in intercepts. In order to estimate the Fixed Effect Model (FEM).

\section{Table 4.4 \\ Fixed Effect Model (FEM) Results}

Dependent Variable: Y

Method: Least Squares Panel

Sample: 20012012

Periods included: 12

Cross-sections included: 20

Total panel (balanced) observations: 240

\begin{tabular}{|c|r|r|r|r|}
\hline \hline Variable & Coefficient & Std. Error & t-Statistics & Prob. \\
\hline & & & & \\
\hline X1 & -3.724163 & 0.746652 & -4.987817 & 0.0000 \\
\hline X2 & -0.168965 & 0.123794 & -1.364883 & 0.1738 \\
\hline X3 & $3.33 E-06$ & $9.98 E-05$ & 0.033334 & 0.9734 \\
\hline Z_X1 & 0.867689 & 0.294488 & 2.946433 & 0.0036 \\
\hline Z_X2 & 0.161001 & 0.187750 & 0.857527 & 0.3921 \\
\hline Z_X3 & 0.000103 & 0.000139 & 0.736655 & 0.4622 \\
\hline C & -0.461447 & 1.627059 & -0.283608 & 0.7770 \\
\hline & & & & \\
\hline & & & & \\
\hline
\end{tabular}

Effects Specification

\begin{tabular}{lrll}
\hline \multicolumn{3}{c}{ Cross-section fixed (dummy variables) } \\
\hline \hline R-squared & 0.632486 Mean dependent var & 0.142107 \\
Adjusted R-squared & 0.577712 & SD dependent var & 0.697110 \\
SE of regression & 0.453008 & Akaike info criterion & 1.377751 \\
Sum squared resid & 42.68495 & Schwarz criterion & 1.841836 \\
Likelihood logs & -133.3301 & Hannan-Quinn Criter. & 1.564744 \\
F-statistics & 11,54726 & Durbin-Watson stat & 2.025799 \\
Prob(F-statistic) & 0.000000 &
\end{tabular}

Al Qalam: Jurnal Ilmiah Keagamaan dan Kemasyarakatan Vol. 16, No. 1 Januari - Juni 2022 
Rico Nur Ilham, Isfenti Sadalia, Nisrul Irawati, Irada Sinta : Risk dan Return Model of Digital Cryptocurrency Asset Investmen in Indonesia

Source: Appendix 5 data processed 2021

\section{Random Effect Model (REM)}

In principle, the Random Effect Model (REM) is different from the Common Effect Model (CEM) and the Fixed Effect Model (FEM), especially this model does not use the ordinary least square principle but uses the maximum likelihood or general least square principle.

Table 4.5

\section{Results of Random Effect Model (REM)}

Dependent Variable : Y

Method: Panel EGLS (Cross-section random effects)

Sample: 20012012

Periods included: 12

Cross-sections included: 20

Total panel (balanced) observations: 240

\begin{tabular}{ccccr} 
Variable & Coefficient & Std. Error & t-Statistics & Prob. \\
\hline X1 & -3.763608 & 0.697173 & -5.398381 & 0.0000 \\
X2 & -0.128047 & 0.120038 & -1.066726 & 0.2872 \\
X3 & -0.000306 & $8.40 \mathrm{E}-05$ & -3.641669 & 0.0003 \\
Z_X1 & 0.841937 & 0.277804 & 3.030683 & 0.0027 \\
Z_X2 & 0.169484 & 0.186994 & 0.906363 & 0.3657 \\
Z_X3 & 0.000213 & 0.000130 & 1.641204 & 0.1021 \\
C & 3.694364 & 1.192147 & 3.098917 & 0.0022 \\
& & & & Rho \\
\hline & Effects Specification & & 0.0000 \\
Random cross-section & & & 0.000000 & 1.0000
\end{tabular}

Weighted Statistics

\begin{tabular}{llll}
\hline R-squared & 0.561607 & Mean dependent var & 0.142107 \\
Adjusted R-squared & 0.538432 & SD dependent var & 0.697110 \\
SE of regression & 0.473608 & Sum squared resid & 50.91720 \\
F-statistics & 24.23335 & Durbin-Watson stat & 1.787175 \\
Prob(F-statistic) & 0.000000 &
\end{tabular}

Unweighted Statistics

\begin{tabular}{llll}
\hline R-squared & 0.561607 & Mean dependent var & 0.142107 \\
Sum squared resid & 50.91720 & Durbin-Watson stat & 1.787175 \\
\hline
\end{tabular}

Al Qalam: Jurnal Ilmiah Keagamaan dan Kemasyarakatan Vol. 16, No. 1 Januari - Juni 2022 
Rico Nur Ilham, Isfenti Sadalia, Nisrul Irawati, Irada Sinta : Risk dan Return Model of Digital Cryptocurrency Asset Investmen in Indonesia

Source: Appendix 5 data processed 2021

\subsubsection{Selection of Estimation Model}

a. Chow test

In determining the estimation model between Common Effect Model (CEM) and Fixed Effect Model (FEM) were performed using the Chow Test with the following results:

Table 4.6

Chow Test Results

Redundant Fixed Effects Tests

Equation: Untitled

Test cross-section fixed effects

\begin{tabular}{lrrr}
\hline \hline Effects Test & Statistics & df & Prob. \\
& & & \\
\hline & & & \\
\hline Cross-section F & 2.111318 & $(19,208)$ & 0.0057 \\
Cross-section Chi-square & 42.325069 & 19 & 0.0016 \\
& & & \\
\hline
\end{tabular}

Source: Appendix 7 Data processed 2021

Based on the results of the Chow test in Table 5.6, it is known that the probability value of chi-square cross section $0.0016<(0.05)$, meaning that the Fixed Effect Model (FEM) estimation model is better than the Common Effect Model (CEM).

b. Hausman test

In determining the estimation model between the Fixed Effect Model (FEM) and the Random Effect Model (REM) the Hausman test is carried out with the following results:

Table 4.7

Hausman Test Results

Correlated Random Effects - Hausman Test

Equation: Untitled

Test cross-section random effects

Test Summary $\quad$ Statistics Chi-Sq. df Prob.

\begin{tabular}{llll}
\hline Random cross-section & 0.000000 & 12 & 1.0000
\end{tabular}

Source: Appendix 8 data processed 2021

Al Qalam: Jurnal Ilmiah Keagamaan dan Kemasyarakatan Vol. 16, No. 1

Januari - Juni 2022 
Rico Nur Ilham, Isfenti Sadalia, Nisrul Irawati, Irada Sinta : Risk dan Return Model of Digital Cryptocurrency Asset Investmen in Indonesia

Based on the Hausman test results in Table 5.7, it is known that the probability value is $1.0000>(0.05)$, meaning that from the Hausman test results it can be concluded that the Random Effect Model (REM) estimation model is better than the Fixed Effect Model (FEM).

\subsubsection{Classical Assumption Test}

If the selected panel data model is the Random Effect Model (REM), then there is no need to test the classical assumptions because the model describes the generalized least square (GLS) which has met the classical assumptions. ${ }^{12}$

\subsubsection{Hypothesis Testing}

In testing the hypothesis, Table 5.8 uses Simultaneous Significance Test (F test) and Partial significance test ( $t$ test) with the following results:

\section{Table 4.8}

\section{F Test and $\mathbf{T}$. Test}

Dependent Variable: $\mathrm{Y}$

Method: Panel EGLS (Cross-section random effects)

Sample: 20012012

Periods included: 12

Cross-sections included: 20

Total panel (balanced) observations: 240

Swamy and Arora estimator of component variances

Variable

Coefficient Std. Error t-Statistics Prob.

\begin{tabular}{|c|c|c|c|c|}
\hline $\mathrm{X} 1$ & -3.763608 & 0.697173 & -5.398381 & 0.0000 \\
\hline $\mathrm{X} 2$ & -0.128047 & 0.120038 & -1.066726 & 0.2872 \\
\hline X3 & -0.000306 & $8.40 \mathrm{E}-05$ & -3.641669 & 0.0003 \\
\hline Z_X1 & 0.841937 & 0.277804 & 3.030683 & 0.0027 \\
\hline Z_X2 & 0.169484 & 0.186994 & 0.906363 & 0.3657 \\
\hline Z_X3 & 0.000213 & 0.000130 & 1.641204 & 0.1021 \\
\hline \multirow[t]{3}{*}{$\mathrm{C}$} & 3.694364 & 1.192147 & 3.098917 & 0.0022 \\
\hline & \multirow{2}{*}{\multicolumn{2}{|c|}{ Effects Specification }} & & \\
\hline & & & SD & Rho \\
\hline \multirow{2}{*}{\multicolumn{3}{|c|}{ Random cross-section }} & 0.000000 & 0.0000 \\
\hline & & & 0.453008 & 1.0000 \\
\hline \multicolumn{5}{|l|}{ Weighted Statistics } \\
\hline R-squared & 0.561607 & \multirow{5}{*}{\multicolumn{2}{|c|}{$\begin{array}{l}\text { Mean dependent var } \\
\text { SD dependent var } \\
\text { Sum squared resid } \\
\text { Durbin-Watson stat }\end{array}$}} & 0.142107 \\
\hline Adjusted R-squared & 0.538432 & & & 0.697110 \\
\hline SE of regression & 0.473608 & & & 50.91720 \\
\hline F-statistics & 24.23335 & & & 1.787175 \\
\hline \multirow[t]{2}{*}{ Prob(F-statistic) } & 0.000000 & & & \\
\hline & \multicolumn{3}{|c|}{ Unweighted Statistics } & \\
\hline
\end{tabular}

${ }^{12}$ Gujarati, "Gujarati Econometric By Example,” עלון הנוטע, 2012.

Al Qalam: Jurnal Ilmiah Keagamaan dan Kemasyarakatan Vol. 16, No. 1 Januari - Juni 2022 
Rico Nur Ilham, Isfenti Sadalia, Nisrul Irawati, Irada Sinta : Risk dan Return Model of Digital Cryptocurrency Asset Investmen in Indonesia

\begin{tabular}{llll}
\hline R-squared & 0.561607 & Mean dependent var & 0.142107 \\
Sum squared resid & 50.91720 & Durbin-Watson stat & 1.787175 \\
& & & \\
\hline
\end{tabular}

Source: Appendix 9 data processed 2021

\section{F Uji test}

In this study, it is known that the number of observations (n) is 240 and the number of parameters $(\mathrm{k})$ is 13 , so that the obtained $\mathrm{df} 1=\mathrm{k}-1=13-1=12 ; \mathrm{df} 2=\mathrm{nk}=240-13=$, then at $=$ 0.05 we get Ftable $=1.795$

Based on Table 5.8, it is known that the Sig value is $0.00000<0.05$. Then it can be concluded simultaneously Beta Crytocurrency (X1), Currency Exchange (X2), Inflation Rate (X3), interaction Beta Cryptocurrency (X1) with Velocity of Cryptocurrency (Z), Inflation Rate (X3) with Velocity of Cryptocurrency (Z), Currency Exchange Rate (X3) with Velocity of Cryptocurrency (Z), with Velocity of Cryptocurrency (Z) has a significant effect on Cryptocurrency Return.

\section{2. $\quad$ t test}

According to $(\mathrm{n})=240$, the number of parameters $(\mathrm{k})=13$, $\mathrm{df}=(\mathrm{nk})=240-13=227$, then at the error rate $=0.05$, we get $\mathrm{t}$ table $=1.970$. Based on Table 5.8, it can be explained that:

a. It is known that the Beta Cryptocurrency coefficient on cryptocurrency Return is negative, namely -3.763 and p-value $0.000<0.05$, then Beta Cryptocurrency has a negative and significant effect on Return cryptocurrency, meaning that every increase in Beta cryptocurrency increases by 1 rupiah, it will decrease Return cryptocurrency 3, 76 percent significantly, and vice versa. Based on Table 5.8, it can be explained that:

b. It is known that the value of the currency exchange coefficient on cryptocurrency returns is negative, namely -0.0003 and the $\mathrm{p}$-value is $0.0003<0.05$, then the currency exchange rate has a negative and significant effect on cryptocurrency returns, meaning that every increase in the currency exchange rate is 1 rupiah. it will reduce the cryptocurrency Return by 0.0003 percent significantly, and vice versa.

d. It is known that the inflation rate coefficient on cryptocurrency returns is negative, namely 0.128 and p-value $0.287>0.05$, so the inflation rate has a negative and insignificant effect on cryptocurrency returns, meaning that every 0.01 percent increase in the inflation rate will decrease cryptocurrency returns by 0.12 percent, and vice versa.

Al Qalam: Jurnal Ilmiah Keagamaan dan Kemasyarakatan Vol. 16, No. 1 Januari - Juni 2022 
Rico Nur Ilham, Isfenti Sadalia, Nisrul Irawati, Irada Sinta : Risk dan Return Model of Digital Cryptocurrency Asset Investmen in Indonesia

\section{Moderation Effect Test}

Moderating variables or moderating variables are variables that can influence (strengthen or weaken) the relationship between the independent variable and the dependent variable. ${ }^{13}$ The moderating variable $(Z)$ in this study is the velocity of cryptocurrency which will be tested whether it can affect the relationship between the dimensions of the risk factor and world commodity price variables on cryptocurrency returns.

In general, moderators are qualitative or quantitative variables that affect the direction and strength of the relationship between independent variables or predictors and dependents or criteria. ${ }^{14}$ Especially in the correlational analysis framework, the moderator is the third variable that affects the zero-order correlation between the other two variables, the moderator effect in the correlational framework can also be said to occur where the direction of the correlation changes. Thus, it can also be said to change the direction of the initial relationship between the independent variables. and dependent from positive to negative.

according to Alan S. Dunk ${ }^{15}$ The MRA cannot be used to test the expectation that X1 and $\mathrm{X} 2$ will have a high influence on $\mathrm{Y}$. This model is a consequence of the MRA testing the significance of the interaction, and does not test for the combined effect of the main effect and the interaction effect on the dependent variable. Differences between significant interactions and effect sizes were not recognized in every problem studied.

Based on the results of the research data processing output that has been carried out using the moderate regression analysis (MRA) method, there are results that the moderating variable velocity of cryptocurrency $(Z)$ gives a negative and significant coefficient at 0.0005 which means the velocity of cryptocurrency variable is a pure moderator. Testing on pure moderators is done by making interaction regression, but the moderator variable does not function as an independent variable. ${ }^{16}$

13 Erlina Yutikawati, "Analisis Laporan Keuangan Untuk Menilai Kinerja Keuangan Pada PT. Rakabu Sejahtra Di Sragen,” Jurnal Riset Ekonomi, Manajemen, Bisnis Dan Akuntansi 8 (2015): 1-10.

${ }^{14}$ Reuben M. Baron and David A. Kenny, "The Moderator-Mediator Variable Distinction in Social Psychological Research. Conceptual, Strategic, and Statistical Considerations," Journal of Personality and Social Psychology 51, no. 6 (1986): 1173-82.

15 Alan S. Dunk, "Reliance on Budgetary Control, Manufacturing Process Automation and Production Subunit Performance: A Research Note," Accounting, Organizations and Society 17, no. 3-4 (1992): 195-203.

16 Imam Ghozali, Aplikasi Analisis Multivariate Dengan Program IBM SPSS 25, (Edisi 9). (Semarang: Badan Penerbit Universitas Diponegoro, 2018).

Al Qalam: Jurnal Ilmiah Keagamaan dan Kemasyarakatan Vol. 16, No. 1 Januari - Juni 2022 
Rico Nur Ilham, Isfenti Sadalia, Nisrul Irawati, Irada Sinta : Risk dan Return Model of Digital Cryptocurrency Asset Investmen in Indonesia

According to Ghozali ${ }^{17}$ If a variable with a significant coefficient value is smaller than the alpha value, which means it is significant and has a negative value, then this variable can be used as a moderating variable. The moderating hypothesis is accepted if the t-count is negative and significant, then this model is free from multicollinearity disturbances. Based on Table 5.8, it can be explained that:

a. It is known that the MRA coefficient value from the interaction velocity of cryptocurrency_beta cryptocurrency with cryptocurrency returns is positive, namely 0.841 with a $\mathrm{T}$ count of $3.030>1.970$ and a p-value of $0.002<0.05$. This indicates that the velocity of cryptocurrency is not a moderating variable that affects the relationship between beta cryptocurrencies. and cryptocurrency returns.

b. It is known that the MRA coefficient value from the interaction velocity of cryptocurrency_currency exchange against cryptocurrency returns is positive, namely 0.0002 with a $\mathrm{T}$ count of $1.641<1.970$ and a p-value of $0.102>0.05$, this indicates that the velocity of cryptocurrency is not a moderator variable or cannot moderate the relationship between currency rates and cryptocurrency returns.

c. It is known that the MRA coefficient value from the interaction of velocity of cryptocurrency_inflation rate on cryptocurrency returns is positive, namely 0.169 with a $\mathrm{T}$ count of $0.906<1.970$ and a p-value of $0.365>0.05$, this shows that the velocity of cryptocurrency is not a moderator variable or cannot moderate the relationship. between inflation rate and cryptocurrency return.

\subsection{Discussion}

\subsubsection{Effect of Cryptocurrency Beta on Cryptocurrency Return}

The results of this study indicate that, if the Beta Cryptocurrency (X1) increases, the Return Cryptocurrency (Y) will decrease. The risks inherent in portfolio investments in the form of cryptocurrencies can be in the form of systematic risk (systematic risk) and company-specific risk (unsystematic risk). The investment model in crypto digital assets has the same level of risk as investing in the money market and capital market, in this study it was revealed that the high risk high return principle does not apply during bearish time conditions in the investment process in the cryptocurrency market. A beta=1 indicates that the cryptocurrency price is moving according to the market movement beta $>1$ indicates that the cryptocurrency price will be more stable in the market.

The CAPM is a model used to calculate the expected rate of return on an asset based on

${ }^{17}$ Imam Ghozali, Aplikasi Analisis Multivariate Dengan Program IBM SPSS 21 Update PLS Regresi (Semarang: Badan Penerbit Universitas Diponegoro, 2013).

Al Qalam: Jurnal Ilmiah Keagamaan dan Kemasyarakatan Vol. 16, No. 1 Januari - Juni 2022 
Rico Nur Ilham, Isfenti Sadalia, Nisrul Irawati, Irada Sinta : Risk dan Return Model of Digital Cryptocurrency Asset Investmen in Indonesia

beta and market, and the cost of equity. Remember that the cost of capital is the discount rate used for present value and future cash flows. The higher the beta of the company, the higher the discount rate of capital costs. Therefore, the higher the discount rate of capital costs will affect the decrease in Return on the Cryptocurrency.

The results of this study are in accordance with the results of the study by Ismayanti \& Yusniar $^{18}$ which shows that the beta risk variable has a negative and significant effect on returns on LQ45 shares. Then in line with research conducted by Koskei ${ }^{19}$, Megawati ${ }^{20}$, Rachmatika ${ }^{21}$ and Musyarofah ${ }^{22}$.

\subsubsection{Effect of Currency Exchange on Cryptocurrency Return}

The results of this study indicate that, if the Currency Exchange (X3) has increased, the Cryptocurrency Return (Y) will decrease. The exchange rate is the price of a currency of one country which is measured or expressed in another currency. Exchange rates play an important role in spending decisions, because they make it possible to translate prices from different countries into the same language.

This study reveals the fact that if the foreign currency exchange rate strengthens then what happens is a decrease in investment returns due to the circulation of Indonesian investment capital in asset transactions in the money market and capital market as well as in the crypto digital asset market must exchange the rupiah exchange rate against foreign currencies, so the nominal investment to buy an investment instrument will increase in terms of equity issued and of course will reduce the rate of return on investment.

\subsubsection{Effect of Inflation Rate on Cryptocurrency Return}

The results of this study indicate that, if the Inflation Rate (X2) increases, the Cryptocurrency Return (Y) will decrease slightly. Inflation is an event that describes the situation and condition where the price of goods has increased and the value of the currency has weakened. ${ }^{23}$

${ }^{18}$ Diah Ismayanti and Meina Wulansari Yusniar, "Pengaruh Faktor Fundamental Dan Risiko (Beta) Terhadap Return Saham Pada Perusahaan Yang Termasuk Dalam Indeks LQ 45," Jurnal Wawasan Manajemen 2 (1), no. Februari 2014 (2014): 1-20.

${ }^{19}$ Loice Koskei, "The Effect of Exchange Rate Risk on Stock Returns in Kenya's Listed Financial Institutions," Research Journal of Finance and Accounting Www.Iiste.Org ISSN 8, no. 3 (2017): 1-5.

${ }^{20}$ Megawati, "Pengaruh Beta Saham Dan Faktor Fundamental Keuangan Terhadap Harga Saham Syariah (Studi Empiris Jakarta Islamic Index Di Bursa Efek Indonesia Tahun 2012-2016)" 6, no. 1 (2018): 2018.

${ }^{21}$ Dian Rachmatika, "Growth Opportunities, Return on Asset Dan Debt To Equity Ratio Terhadap Return Saham," Tesis, 2006.

${ }^{22}$ S. Musyarofah, "Pengaruh Beta Pasar Dan Dividend Payout Ratio Terhadap Return Saham (Studi Pada Perusahaan Perbankan Yang Terdaftar Di Bursa Efek Indonesia Periode 2010-2013)," Jurnal Administrasi Bisnis S1 Universitas Brawijaya 26, no. 2 (2015): 86313.

23 Azim Muhammad Fahmi et al., "Regression Based Analysis for Bitcoin Price Prediction," International Journal of Engineering \& Technology 7, no. 4.38 (2018): 1070.

Al Qalam: Jurnal Ilmiah Keagamaan dan Kemasyarakatan Vol. 16, No. 1 Januari - Juni 2022 
Rico Nur Ilham, Isfenti Sadalia, Nisrul Irawati, Irada Sinta : Risk dan Return Model of Digital Cryptocurrency Asset Investmen in Indonesia

This study reveals that inflation has a negative but indirect effect on investment in the cryptocurrency market, because the effect of inflation first affects macroeconomic factors and the rate of economic growth so that the result of the weakening of Indonesia's economic growth can lead to a decrease in investment interest and will be directly proportional as well. have a negative impact on decreasing investment returns both in the money market and capital market as well as investment in the cryptocurrency market. Inflation is defined as the tendency of an increase in the price of products as a whole so that there is a decrease in the purchasing power of money. ${ }^{24}$ Based on the opinion of experts, it can be concluded that inflation is a process of increasing prices continuously which causes a decrease in the value of the currency and people's purchasing power.

\subsubsection{Effect of X1*Z Moderation on Cryptocurrency Return}

The results of this study indicate that, if X1*Z Moderation increases, the Cryptocurrency Return (Y) will remain or Constant. This study reveals the fact that the Velocity of cryptocurrency does not affect the relationship between beta cryptocurrencies and investment returns, so the higher the turnover rate for digital crypto assets, it will not necessarily reduce returns, type in digital assets that have been purchased at a certain price and then sold for a short period of time. market conditions and economic growth conditions if when selling crypto digital assets during a sluggish economic period or stagnant economic growth, the returns obtained will decrease.

The results of this study are in accordance with the results of the study by Ismayanti \& Yusniar $^{25}$ which shows that the beta risk variable has a negative and significant effect on the return on LQ45 shares. Then there is a justification for the research conducted by the author showing that the Velocity of Cryptocurrency variable moderates the effect of Beta Cryptocurrency on returns on Bitcoin. Cryptocurrency beta is a measure of the volatility, or systematic risk and security of a cryptocurrency portfolio in the market. Beta is used in the capital asset pricing (CAPM) model.

\subsubsection{Effect of X2*Z Moderation on Cryptocurrency Return}

The results of this study indicate that, if X2*Z Moderation increases, the Cryptocurrency Return (Y) will remain or be constant. In this study, it was revealed that the velocity of cryptocurrency did not significantly strengthen the effect of currency exchange rates on cryptocurrency returns, this happened because considering that the determination of the rupiah exchange rate which adheres to a free floating system is strongly influenced by the global economy and the amount of Indonesia's balance of payments, whether the situation is surplus or deficit.

${ }^{24}$ Tandelilin, Portofolio Dan Investasi (Kanisius, 2010).

25 Ismayanti and Yusniar, "Pengaruh Faktor Fundamental Dan Risiko (Beta) Terhadap Return Saham Pada Perusahaan Yang Termasuk Dalam Indeks LQ 45.”

Al Qalam: Jurnal Ilmiah Keagamaan dan Kemasyarakatan Vol. 16, No. 1

Januari - Juni 2022 
Rico Nur Ilham, Isfenti Sadalia, Nisrul Irawati, Irada Sinta : Risk dan Return Model of Digital Cryptocurrency Asset Investmen in Indonesia

Although the turnover rate and movement of crypto digital assets is getting faster, it does not necessarily increase investment in the crypto digital asset market.

The results of this study are in accordance with the research by Pujawati et al. ${ }^{26}$ which shows that the currency exchange variable has a negative and significant effect on stock returns in the hospitality industry. There is justification in the research conducted by the author and shows that the Velocity of Cryptocurrency variable does not moderate the effect of Currency Exchange on returns on Bitcoin. Currency exchange rate is the price of a currency of one country measured or expressed in another currency. While the research that explains the relationship of the currency exchange rate variable is placed as a moderating variable on stock returns, namely research conducted by Mantari \& $\mathrm{Sn}^{27}$ Moderation Effect of Exchange Rate to Signaling Theory Validity in Indonesia Stock Exchange.

\subsubsection{Effect of X3*Z Moderation on Cryptocurrency Return}

The results of this study indicate that, if $\mathrm{X} 3 * \mathrm{Z}$ Moderation increases, the Cryptocurrency Return (Y) will remain or be constant. This study reveals the fact that the velocity of cryptocurrency does not strengthen the negative influence of inflation on cryptocurrency investment returns, meaning that the faster the turnover rate and the movement of crypto digital assets will not necessarily reduce investment returns, plus the inflation rate will further hamper the pace of economic growth. Due to unstable economic growth and high inflation rates, this will greatly reduce investment interest in both the money market and capital market as well as investment in the cryptocurrency market so that the returns obtained by investors will decrease.

The results of this study are in accordance with the results of the study by Suriyani \& Sudiartha $^{28}$ which shows that the inflation variable has no significant negative effect on property and real estate stock returns. There is a justification in the research conducted by the author which shows that the Velocity of Cryptocurrency variable moderates the effect of the Inflation Rate on the return on Bitcoin. Inflation is an event that describes the situation and condition where the price of goods has increased and the value of the currency has weakened. ${ }^{29}$

\subsection{Research Synthesis}

${ }^{26}$ Putu Eka Pujawati, I Gusti Bagus Wiksuana, and Luh Gede Sri Artini, "Pengaruh Nilai Tukar Rupiah Terhadap Return Saham Dengan Profitabilitas Sebagai Variabel Intervening," E-Jurnal Ekonomi Dan Bisnis Universitas Udayana 4, no. 4 (2015): 220-42.

${ }^{27}$ Jonnardi Sutan Mantari and Nuryasman Sn, "Moderation Effect of Exchange Rate to Signaling Theory Validity in Indonesia Stock Exchange," Business and Management Studies 3, no. 1 (2017): 80.

${ }^{28}$ Ni Kadek Suriyani and Gede Mertha Sudiartha, "Pengaruh Tingkat Suku Bunga, Inflasi Dan Nilai Tukar Terhadap Return Saham Di Bursa Efek Indonesia," E-Jurnal Manajemen Universitas Udayana 7, no. 6 (2018): 3172.

29 Andi Fahmi Lubis, "Market Power Of Indonesian Banking," Buletin Ekonomi Moneter Dan Perbankan 14, no. 3 (2012): 225-44.

Al Qalam: Jurnal Ilmiah Keagamaan dan Kemasyarakatan Vol. 16, No. 1

Januari - Juni 2022 
Rico Nur Ilham, Isfenti Sadalia, Nisrul Irawati, Irada Sinta : Risk dan Return Model of Digital Cryptocurrency Asset Investmen in Indonesia

Based on the results of the study, there is a negative and significant effect between Cryptocurrency Beta, Inflation Rate, and Currency Exchange on Cryptocurrency Returns, so that the dimensions of the risk factor variable can be used as a model for assessing negative returns on cryptocurrency investments. This means that if there is a situation where the risk factor variables, namely Cryptocurrency Beta, Inflation Rate, and Currency Exchange are increasing in intensity, it will have an impact on decreasing Cryptocurrency investment returns.

The results of this study indicate that in Indonesia the turnover rate of crypto digital assets will have a positive effect and be able to increase investment returns when economic growth is stable and when export commodity prices are increasing, but on the contrary when inflation increases and the rupiah exchange rate weakens against foreign currencies that will result in a weakening of Indonesia's economic growth rate, then this will make the velocity of cryptocurrency a factor that reduces investment returns in the crypto digital asset market.

\subsection{Novelty Research}

Based on the novelty of the findings from the results of this study, the authors make the digital crypto asset investment instrument which has the largest market cap in Indonesia as the object of research in order to be different from previous studies that place companies listed on the Indonesian stock exchange as the object of research. In order to be a source of reference for investors in choosing an investment strategy, the authors add the velocity of cryptocurrency as a moderating variable.

\section{REFERENCES}

Ali, Mashud (2006) Risk Management (Banking and Business Strategy in Facing the Challenges of Business Globalization). Jakarta: PT Raja Grafindo Persada.

Baron, Reuben M., and David A. Kenny. "The Moderator-Mediator Variable Distinction in Social Psychological Research. Conceptual, Strategic, and Statistical Considerations." Journal of Personality and Social Psychology 51, no. 6 (1986): 1173-82. https://doi.org/10.1037/0022-3514.51.6.1173.

Dunk, Alan S. "Reliance on Budgetary Control, Manufacturing Process Automation and Production Subunit Performance: A Research Note." Accounting, Organizations and Society 17, no. 3-4 (1992): 195-203. https://doi.org/10.1016/0361-3682(92)90020-S.

Erlina Yutikawati. "Analisis Laporan Keuangan Untuk Menilai Kinerja Keuangan Pada Pt. Rakabu Sejahtra Di Sragen.” Jurnal Riset Ekonomi, Manajemen, Bisnis Dan Akuntansi 8 (2015): $1-10$.

Ghofur, Ruslan. "Distribution Policy on Islamic Economics." Islamic Journal of Islamic Studies, 2012.

Ghozali, Imam (2018) Aplikasi Analisis Multivariate Dengan Program IBM SPSS 25. (Edisi 9). Semarang: Badan Penerbit Universitas Diponegoro.

Ghozali, Imam (2013) Aplikasi Analisis Multivariate Dengan Program IBM SPSS 21Update PLS Regresi. Semarang: Badan Penerbit Universitas Diponegoro.

Gitman, LJ, and CJ Zutter (2012) Principles of Managerial Finance. Pearson: Boston.

Al Qalam: Jurnal Ilmiah Keagamaan dan Kemasyarakatan Vol. 16, No. 1

Januari - Juni 2022 
Rico Nur Ilham, Isfenti Sadalia, Nisrul Irawati, Irada Sinta : Risk dan Return Model of Digital Cryptocurrency Asset Investmen in Indonesia

Gujarati. "Gujarati Econometric By Example.” עלון הנוטע, 2012.

Ilham, Rico Nur. "Pengaruh Manajemen Laba Terhadap Nilai Perusahaan Dengan Good Corporate Governance," 2017.

Ilham, Rico Nur, Erlina, Khaira Amalia Fachrudin, and Amlys Syahputra Silalahi. "Positive Effect in Efficient Application of Corporate Social Responsibility in PT.Indonesia Asahan Aluminium as an Indicator Enhancement Efforts Public Welfare North Sumatra,” 2019. https://doi.org/10.2991/icoi-19.2019.96.

Ismayanti, Diah, and Meina Wulansari Yusniar. "Pengaruh Faktor Fundamental Dan Risiko (Beta) Terhadap Return Saham Pada Perusahaan Yang Termasuk Dalam Indeks LQ 45.” Jurnal Wawasan Manajemen 2 (1), no. Februari 2014 (2014): 1-20.

Jogiyanto, Hartono (2013) Misguided Business Research Methodology and Experiences. 5th ed. Yogyakarta: BPFE-Yogyakarta.

Juanda, Bambang. "Ekonometrika Deret Waktu: Teori Dan Aplikasi," 2012, 1-6.

Koskei, Loice. "The Effect of Exchange Rate Risk on Stock Returns in Kenya's Listed Financial Institutions." Research Journal of Finance and Accounting Www.Iiste.Org ISSN 8, no. 3 (2017): $1-5$.

Labombang, M. "Risk Management in Construction Projects." SMARTek Journal, no. 9 (2011).

Lubis, Andi Fahmi. "MARKET POWER OF INDONESIAN BANKING." Buletin Ekonomi Moneter Dan Perbankan 14, no. 3 (2012): 225-44. https://doi.org/10.21098/bemp.v14i3.403.

Mantari, Jonnardi Sutan, and Nuryasman Sn. "Moderation Effect of Exchange Rate to Signaling Theory Validity in Indonesia Stock Exchange." Business and Management Studies 3, no. 1 (2017): 80. https://doi.org/10.11114/bms.v3i1.2259.

Megawati. "Pengaruh Beta Saham Dan Faktor Fundamental Keuangan Terhadap Harga Saham Syariah (Studi Empiris Jakarta Islamic Index Di Bursa Efek Indonesia Tahun 2012-2016)" 6, no. 1 (2018): 2018.

Muhammad Fahmi, Azim, Noor Azah Samsudin, Aida Mustapha, Nazim Razali, and Shamsul Kamal Ahmad Khalid. "Regression Based Analysis for Bitcoin Price Prediction." International Journal of Engineering \& Technology 7, no. 4.38 (2018): 1070. https://doi.org/10.14419/ijet.v7i4.38.27642.

Musyarofah, S. "Pengaruh Beta Pasar Dan Dividend Payout Ratio Terhadap Return Saham (Studi Pada Perusahaan Perbankan Yang Terdaftar Di Bursa Efek Indonesia Periode 2010-2013).” Jurnal Administrasi Bisnis S1 Universitas Brawijaya 26, no. 2 (2015): 86313.

Penman, Stephen, and Francesco Reggiani. "Returns to Buying Earnings and Book Value: Accounting for Growth and Risk." Review of Accounting Studies 18, no. 4 (2013): 102149. https://doi.org/10.1007/s11142-013-9226-y.

Pujawati, Putu Eka, I Gusti Bagus Wiksuana, and Luh Gede Sri Artini. "Pengaruh Nilai Tukar Rupiah Terhadap Return Saham Dengan Profitabilitas Sebagai Variabel Intervening." $E$ Jurnal Ekonomi Dan Bisnis Universitas Udayana 4, no. 4 (2015): 220-42.

Rachmatika, Dian. "Growth Opportunities , Return on Asset Dan Debt To Equity Ratio Terhadap Return Saham." Tesis, 2006.

Siringoringo, Renniwaty. "Perbankan Di Indonesia." Buletin Ekonomi Moneter Dan Perbankan juli (2012): 1-24.

Suriyani, Ni Kadek, and Gede Mertha Sudiartha. "Pengaruh Tingkat Suku Bunga, Inflasi Dan Nilai Tukar Terhadap Return Saham Di Bursa Efek Indonesia." E-Jurnal Manajemen $\begin{array}{llllll}\text { Universitas } & \text { Udayana } & 7, & \text { no. } & 6 & \text { (2018): }\end{array}$ https://doi.org/10.24843/EJMUNUD.2018.v07.i06.p12.

Tandelilin, Eduardus (2010) Portofolio Dan Investasi. Kanisius.

Al Qalam: Jurnal Ilmiah Keagamaan dan Kemasyarakatan Vol. 16, No. 1

Januari - Juni 2022 